\title{
Cooperative Regulation of Calcitonin Gene-related Peptide Levels in Rat Sensory Neurons via Their Central and Peripheral Processes
}

\author{
Y. Inaishi, ${ }^{1}$ Y. Kashihara, ${ }^{1}$ M. Sakaguchi, ${ }^{a}$ H. Nawa, ${ }^{2}$ and M. Kuno ${ }^{1}$ \\ ${ }^{1}$ National Institute for Physiological Sciences, Okazaki 444, Japan and ${ }^{2}$ Institute of Immunology, Kyoto University Faculty \\ of Medicine, Kyoto 606-01, Japan
}

\begin{abstract}
Calcitonin gene-related peptide (CGRP) is present in both motor and sensory neurons and transported in the somatofugal direction. CGRP levels in sensory neurons are assumed to be regulated by NGF supplied from their peripheral targets. In cultured sensory neurons, however, a basal level of CGRP persists even without NGF. This suggests that some additional factors may be involved in regulation of CGRP levels of sensory neurons. The present study shows that chronic section of the sciatic nerve in the rat reduces CGRP levels in the lumbar dorsal root ganglia (DRG), whereas section of dorsal roots increases CGRP levels in the DRG. This increased CGRP level by dorsal rhizotomy was associated with enhancement of the CGRP mRNA expression in the DRG. Thus, CGRP expression in DRG appears to be regulated reciprocally via their central and peripheral processes. When the sciatic nerve had been cut 1 week previously, however, dorsal rhizotomy no longer increased CGRP levels in the lumbar DRG. Therefore, stimulation of CGRP synthesis in the DRG by dorsal rhizotomy may require the integrity of the peripheral processes. When NGF had been infused into the central stump of the cut sciatic nerve, dorsal rhizotomy again increased CGRP levels in the DRG, despite prior section of the peripheral processes. We conclude that CGRP expression in sensory neurons may be regulated by cooperative action of some factors derived via their central processes and NGF supplied from the peripheral targets.
\end{abstract}

Many peptides are present in dorsal root ganglion (DRG) cells (Hökfelt et al., 1980, 1986; Ju et al., 1987). In a given sensory neuron, one or more peptides coexist with a classical transmitter substance (Hökfelt et al., 1986). The functional significance of these peptides is not clear. However, the coexistence of particular peptides occurs in a manner specific to subpopulation of sensory neurons (Price, 1985; Ju et al., 1987) and is related to the type of their peripheral targets (O'Brien et al., 1989). McMahon and Gibson (1987) have reported that the expression of peptides in sensory neurons can be altered following cross-reinncrvation of the peripheral axons between different target tissues. Differential peripheral regulation of peptides in sensory

\footnotetext{
Received June 19, 1991; revised Sept. 9, 1991; accepted Sept. 18, 1991.

This work was supported by a research grant from the Ministry of Education, Science and Culture of Japan. We thank Dr. M. Rosenfeld for his kind gift of the probe for CGRP mRNA and Dr. S. Nakanishi for advice. We are grateful to Ms. C. Takasu for her excellent technical assistance.

Correspondence should be addressed to Motoy Kuno, Department of Physiology, Kyoto University Faculty of Medicine, Kyoto 606-01, Japan.

a Present address: Biological Laboratory, Kyushu University College of General Education, Fukuoka 810, Japan.

Copyright (c) 1992 Society for Neuroscience $0270-6474 / 92 / 120518-07 \$ 05.00 / 0$
}

neurons has also been suggested by the reaction to nerve injury. In response to peripheral axotomy, the levels of vasoactive intestinal polypeptide and galanin are enhanced in sensory neurons (Nielsch and Keen, 1989; Villar et al., 1989, 1991), whereas the expression of substance $P$ or calcitonin gene-related peptide (CGRP) is reduced (Jessell et al., 1979; Fitzgerald et al., 1985; Bisby and Keen, 1986; Noguchi et al., 1989, 1990; Henken et al., 1990; Villar et al., 1991; Wong and Oblinger, 1991). Reduced levels of substance $P$ in the lumbar DRG after section of the sciatic nerve can be reversed by infusion of NGF into the central stump of the cut nerve in adult rats (Fitzgerald et al., 1985; Wong and Oblinger, 1991). Thus, the expression of some peptides in sensory neurons appears to be maintained by NGF supplied from the peripheral targets (Goedert et al., 1981).

Consistent with this notion, the expression of CGRP as well as substance $P$ has been shown to be upregulated by NGF in DRG cells cultured from adult rats (Lindsay and Harmar, 1989; Lindsay et al., 1989). In cultured DRG cells, however, a basal level of substance $P$ or CGRP persists after the deprivation of NGF or even in the presence of excessive anti-NGF antibodies (Lindsay et al., 1989). It is then possible that these peptides in DRG may bc rcgulated by some other factors in addition to NGF. In adult rats, the CGRP content in DRG cells has been shown to increase 2 weeks after section of the dorsal roots (Villar et al., 1991). This suggests that some additional factors might be derived via the central processes of DRG cells for regulation of their CGRP levels. Based on this surmise, we examined regulation of CGRP levels in rat DRG cells in vivo. The results show that CGRP levels and the expression of CGRP mRNA in DRG are enhanced $1 \mathrm{~d}$ after section of their dorsal roots. However, this effect required the integrity of the peripheral processes of sensory neurons or the supply of NGF from the periphery. Thus, the expression of CGRP in sensory neurons may be regulated cooperatively via their central and peripheral processes.

\section{Materials and Methods}

Preparation. Wistar rats, about 5 weeks old, were anesthetized by an intraperitoneal injection of sodium pentobarbital $(50 \mathrm{mg} / \mathrm{kg})$. The sciatic nerve was transected in the upper thigh level on the left side. In some experiments, the left hindlimb was removed below the site of nerve section after ligation of the femoral blood vessels. Also, in three animals, the fourth and fifth lumbar $\left(\mathrm{L}_{4}, \mathrm{~L}_{5}\right)$ spinal nerves were cut just outside of the vertebral column at 5-8 mm peripheral to their DRG. Dorsal rhizotomy was performed in the $L_{4}$ and $L_{5}$ segments at 5-8 $\mathrm{mm}$ from the DRG. After a postoperative period of $1-15 \mathrm{~d}$, the rat was anesthetized with sodium pentobarbital and the $L_{4}$ and $L_{5} D R G$ were excised from the operated side as well as from the contralateral side for measurements of their CGRP contents.

Enzyme immunoassay of CGRP. The excised DRG were homogenized with a glass-glass homogenizer in $10 \mathrm{~mm}$ PBS (pH 7.0). The homogenates were centrifuged for $10 \mathrm{~min}$ at $10,000 \times \mathrm{g}$, and aliquots 

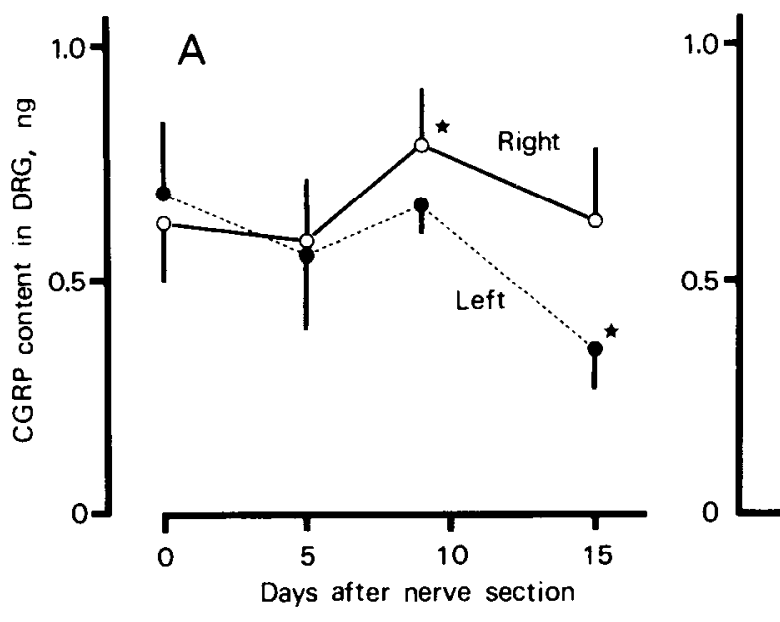

B

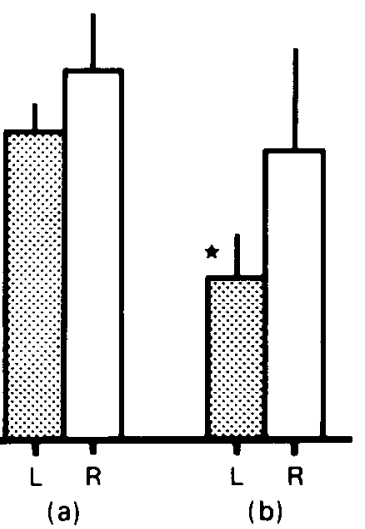

Figure 1. Changes in the CGRP content of the lumbar DRG following section of the left sciatic nerve. $A$, CGRP contents of $\mathrm{L}_{4}$ and $\mathrm{L}_{5}$ DRG on the operated side (left, solid circles) and on the contralateral side (right, open circles) after section of the left sciatic nerve. Each point is the mean with SD (vertical bars) from 3-10 rats. Asterisks, significant difference from the normal level (at day 0). B, CGRP contents in the lumbar DRG on the operated side (shaded columns) and on the contralateral side (open columns) measured $9 \mathrm{~d}$ after section of the left sciatic nerve. $a$, Sciatic nerve section alone. $b$, Removal of the hindlimb below the site of nerve section. Vertical bars, SD $(n=3)$. Asterisk, significant difference from the results in $a$.

of the supernatants were used for two-site enzyme immunoassay of CGRP. This assay procedure has been described previously in detail (Kashihara et al., 1989). Briefly, the antiserum raised in rabbits by injecting synthetic rat $\alpha$-CGRP (Peptide Institute, Inc.) was purified by affinity chromatography. Polystyrene beads $(3.2 \mathrm{~mm}$ in diameter) were coated with the affinity-purified antibodies. These beads were exposed to the test solution overnight at $4^{\circ} \mathrm{C}$. CGRP bound to individual beads was then assayed by the enzyme reaction of HRP that was conjugated to anti-CGRP Fab'. The CGRP-immunoreactive material in neural tissues measured by this method coincided with synthetic rat CGRP in fractional distributions separated by gel filtration (Kashihara et al., 1989). The lower limit of this assay was about $2 \mathrm{pg}$ or $20 \mathrm{pg} / \mathrm{ml}$.

Nerve growth factor. $\beta$-NGF was isolated from submaxillary glands of male mice as described by Varon et al. (1972). A mini osmotic pump (Alza Corp.) was filled with Krebs's solution containing $\beta$-NGF $(0.055$ $\mathrm{mg} / \mathrm{ml}$ or $0.55 \mathrm{mg} / \mathrm{ml}$ ). The connecting tube made of silicone rubber was also filled with the same solution, and the central stump of the cut sciatic nerve on the left side was tightly inserted into the tip of the connecting tube. The tube tip was fixed through the nerve sheath at 3 places with 8-0 silk sutures. The osmotic pump was placed subcutaneously in a pocket of skin on the back, and the solution was delivered at a rate of $0.5 \mu \mathrm{l} / \mathrm{hr}$ for $12 \mathrm{~d}$. In some experiments, NGF was applied systemically, placing the tip of the connecting tube into the interscapular subcutaneous space, instead of the cut nerve end. In four animals, the serum level of NGF was measured on the last day of the NGF application. The procedure of two-site enzyme immunoassay for NGF (Furukawa et al., 1983; Korsching and Thoenen, 1983) was basically similar to that used for assay of CGRP. The antiserum was raised in rabbits by injecting mouse $\beta$-NGF, and the IgG fraction was isolated by a protein A sepharose CL-4B column (Pharmacia Fine Chemicals). NGF bound to individual beads $(3.2 \mathrm{~mm}$ in diameter) coated with the antibodies was assayed by the anti-NGF Fab' linked to HRP in a manner similar to that for CGRP assay. The lower limit of this assay for NGF was $1.5 \mathrm{pg}$ or $15 \mathrm{pg} / \mathrm{ml}$.

Northern blotting. The left and right DRG in the fourth and fifth lumbar segments were excised from 10 normal rats and 10 rats in which the left lumbar dorsal roots had been cut $5 \mathrm{~d}$ previously. Total RNA was extracted by the guanidinium thiocyanate method, separated on an $1.5 \%$ formaldehyde-agarose gel, and blotted on Biodyne nylon filter (Pall). The DNA probe (1.2 kilobases) of the 3' sequence of the rat $\alpha$-CGRP genom was a gift of Dr. M. Rosenfeld (Eukaryotic Regulatory Biology Program, UCLA, San Diego, School of Medicine, La Jolla, CA) and was labeled with ${ }^{32} \mathrm{P}$ by random hexanucleotide priming (Feinberg and Vogelstein, 1983). Hybridization was performed at $42^{\circ} \mathrm{C}$. Radioactivity of each spot was measured by a Fuji Bioimaging analyzer (BAS 2000) and visualized by exposing to x-ray film for illustrative purposes. The probe for CGRP mRNA was then removed under high stringent conditions $\left(0.1 \times\right.$ saline-Na citrate and $0.1 \% \mathrm{SDS}$ at $\left.65^{\circ} \mathrm{C}\right)$, and the same filter was probed with ${ }^{32} \mathrm{P}$ end-labeled oligo DNA (CCATTCGCAGTTTCACTG) that is complementary to rat $18 \mathrm{~S}$ ribosomal RNA sequence. Thus, $18 \mathrm{~S}$ ribosomal RNA was used as the internal control (see Fig. 3B).
All values presented in the text give the mean and its standard deviation.

\section{Results}

Effects of section of the sciatic nerve on CGRP levels in DRG The amount of CGRP in $\mathrm{L}_{4}$ and $\mathrm{L}_{5} \mathrm{DRG}$ on each side was measured either in normal, unoperated rats or in rats 5-15 d after transection of the left sciatic nerve at the upper thigh level. The CGRP content in the lumbar DRG on the operated side remained unchanged up to $9 \mathrm{~d}$ but was significantly reduced 15 $\mathrm{d}$ after nerve section (Fig. $1 A$, solid circles). This is basically similar to the behavior of substance $P$ in the lumbar DRG following peripheral axotomy. However, CGRP levels in the DRG on the contralateral side increased slightly but significantly $9 \mathrm{~d}$ after section of the left sciatic nerve (Fig. $1 \mathrm{~A}$, open circles). In the case of substance $\mathrm{P}$, its content in the lumbar DRG on the contralateral side remains unchanged (Jessell et al., 1979) or is also reduced following unilateral section of the sciatic nerve (Villar et al., 1989).

Following section of a peripheral nerve, NGF and the lowaffinity NGF receptor are newly synthesized in Schwann cells around degenerating nerve fibers (Taniuchi et al., 1986, 1988; Heumann et al., 1987a,b; Johnson et al., 1988). NGF produced in Schwann cells has been suggested to exert trophic influence locally on the cut and regenerating nerve fibers. In order to examine this possible influence, the left hindlimb was entirely removed below the site of sciatic nerve transection. Figure $1 B$ compares the results obtained $9 \mathrm{~d}$ after section of the left sciatic nerve with (b) and without (a) limb amputation. When the hindlimb had been removed, no increase in the CGRP content was observed in the contralateral, control DRG. Moreover, CGRP levels in the DRG on the operated side were markedly diminished. These results suggest that some signal derived from the region peripheral to the site of nerve section increases the CGRP content in the DRG on the contralateral side and counteracts a reduction of CGRP levels in axotomized DRG cells.

\section{Effects of section of dorsal roots on CGRP levels in the DRG}

Figure 2 shows changes in CGRP levels in the lumbar DRG following section of the left lumbar $\left(\mathrm{L}_{4}, \mathrm{~L}_{5}\right)$ dorsal roots. In contrast to peripheral axotomy, CGRP levels in the DRG on the operated side increased within $1 \mathrm{~d}$ after dorsal rhizotomy, and this increase was maintained for at least $15 \mathrm{~d}$. The CGRP 
Figure 2. Changes in the CGRP content of the lumbar DRG following section of the left lumbar dorsal roots. Solid circles, CGRP contents in the DRG on the operated side (left). Open circles, results obtained from the DRG on the contralateral side (right). Each point is the mean with SD (vertical bars) from 3-10 rats. Asterisks, significant difference from the normal level.

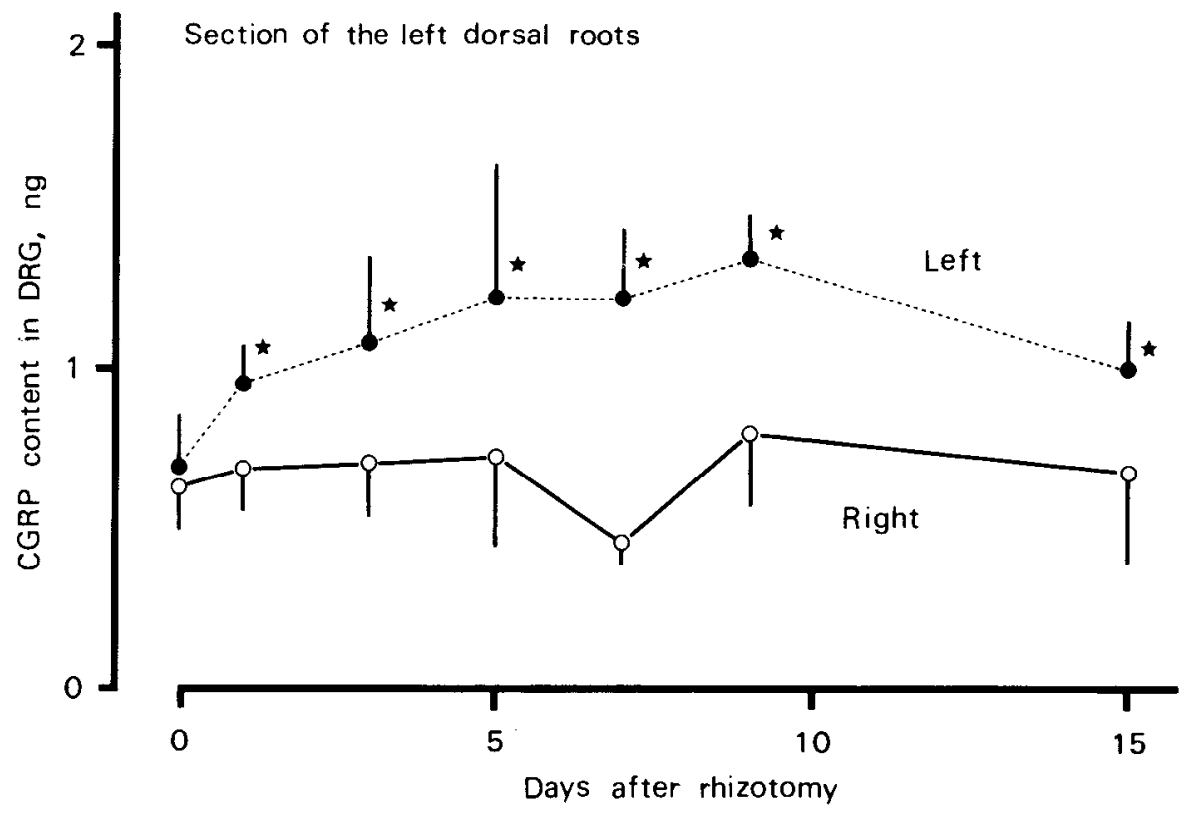

content in the DRG on the contralateral side remained unaltered. Villar et al. (1991) have reported that the CGRP content in DRG increases $14 \mathrm{~d}$ but not $3 \mathrm{~d}$ after dorsal rhizotomy. The explanation for the difference between their and our results is not clear.

Since the lumbar dorsal roots were cut at 5-8 $\mathrm{mm}$ from their DRG, the site of transection was closer to the DRG in central axotomy than in peripheral axotomy. It might be argued that increased CGRP levels in the DRG after rhizotomy could be due to accumulation of CGRP as a result of interruption of its somatofugal transport (Villar et al., 1991). To test this possibility, the spinal nerves $\left(\mathrm{L}_{4}, \mathrm{~L}_{5}\right)$ were cut just outside of the vertebral column at 5-8 mm peripheral to their DRG in three rats. Under this condition, there was no sign of an increase in the CGRP content of the DRG on the operated side $9 \mathrm{~d}$ after nerve section $(0.48+0.067 \mathrm{ng} ; n=3)$. It should be noted that the amount of CGRP transported in the somatofugal direction is greater in the peripheral sensory fibers than in the dorsal roots (Kashihara et al., 1989). Therefore, elevated CGRP levels in the DRG after rhizotomy cannot be attributed to accumulation resulting from interruption of its axonal transport.

The above observations were complemented by Northern blot analysis for the expression of CGRP mRNA in DRG (Fig. 3). CGRP mRNA levels were, on average, 1.4-fold higher in the DRG measured $5 \mathrm{~d}$ after rhizotomy (lanes 1-3) than in the DRG on the contralateral, control side (lanes 4-6) or in the DRG of normal, unoperated rats (lanes 7-9). Thus, increased CGRP levels in DRG induced by rhizotomy must be due to enhancement of CGRP synthesis.

\section{Cooperation of CGRP regulation via central and peripheral processes}

From the preceding results, the CGRP content in sensory neurons appears to be regulated reciprocally via their central and peripheral processes. Do these two regulatory effects interact? To address this question, dorsal rhizotomy was combined with section of the peripheral nerve. The CGRP content in DRG was 1.7 times higher on the operated side than on the control side
$5 \mathrm{~d}$ after section of the left dorsal roots (Fig. $4 A$ ). However, this effect was no longer present when the left sciatic nerve had been cut 1 week prior to the left dorsal rhizotomy (Fig. $4 B$ ). Thus, stimulation of CGRP synthesis in sensory neurons induced by rhizotomy may require the integrity of their peripheral processes or the presence of some factors normally supplied from their peripheral targets.

Since NGF is one of the trophic factors supplied to sensory neurons from the periphery, we examined the possible involvement of NGF in the effect of dorsal rhizotomy. Immediately after section of the left sciatic nerve, NGF was chronically applied to the central stump of the cut nerve with an indwelling osmotic pump (Fitzgerald et al., 1985; Wong and Oblinger, 1991). One week after this operation, the left lumbar dorsal roots were cut, and the CGRP content in the DRG was measured $5 \mathrm{~d}$ later. NGF infusion was maintained during the $12 \mathrm{~d}$ period. As shown in Figure $4 C$, the CGRP content in the DRG on the operated side was markedly elevated. When NGF had been infused to the cut left sciatic nerve for $12 \mathrm{~d}$ without dorsal rhizotomy, CGRP levels in the DRG on the operated side also increased (Fig. $4 D$ ). However, the CGRP content in the DRG increased by treatment with NGF was 1.6 times higher $(p<$ 0.001 ) in the animals with dorsal rhizotomy than that in those without rhizotomy. Thus, despite the prior transection of the sciatic nerve, upregulation of CGRP levels in DRG by dorsal rhizotomy could be expressed if NGF was infused into the cut nerve end.

\section{Effects of NGF on CGRP levels in axotomized and intact DRG cells}

In the experiments described (Fig. $4 C, D$ ), a solution containing $0.055 \mathrm{mg} / \mathrm{ml}$ of $\beta$-NGF (about $2 \mu \mathrm{M}$ ) was delivered at a rate of $0.5 \mu \mathrm{l} / \mathrm{hr}$ to the cut end of the left sciatic nerve. Under this condition, the CGRP content in the DRG on the contralateral side also tended to increase (R, Fig. $4 C, D$ ). It is likely that some NGF applied to the cut nerve end might leak into blood circulation, thereby causing upregulation of CGRP levels in the DRG on the contralateral side. In fact, the serum sampled on 


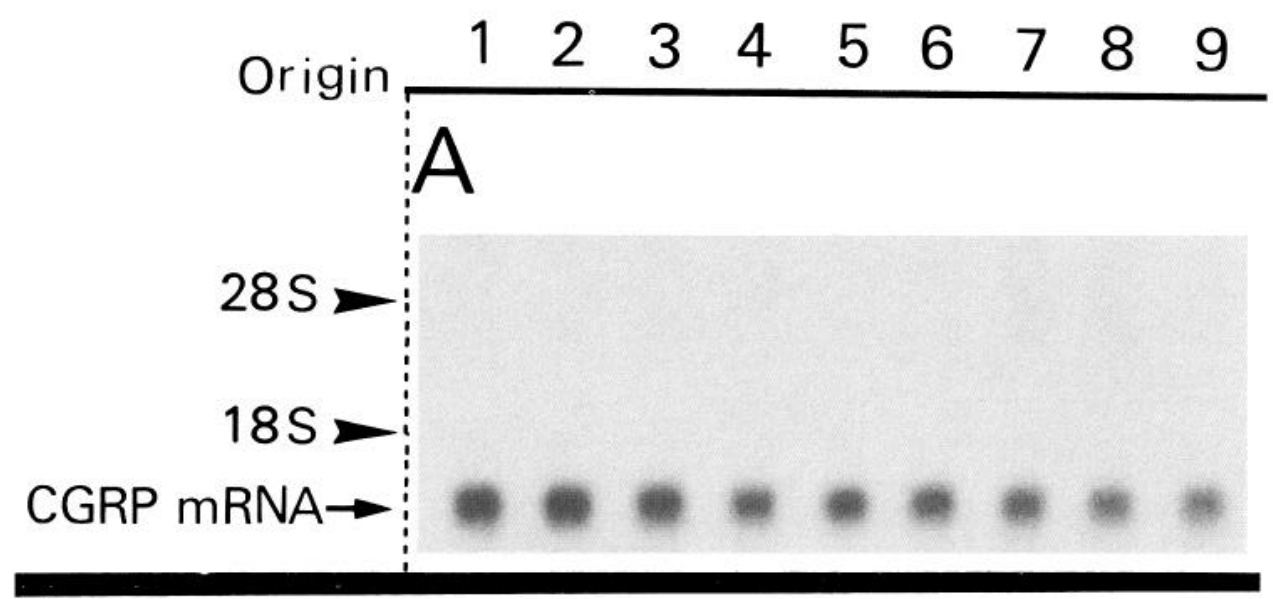

$18 \mathrm{~S}$ rRNA $\rightarrow$
Figure 3. Northern blot analysis of CGRP mRNA levels in the lumbar DRG. RNA samples consisted of 2.8 $\mu \mathrm{g}$ on each lane. $A$, autoradiography for CGRP mRNA; $B$, for $18 \mathrm{~S}$ ribosomal RNA. For each set of three lanes, the mean \pm SD for radioactivity of the bands, measured by Fuji Bioimaging analyzer, is given in parentheses in the following data. CGRP MRNA: lanes I3 , on the operated side $5 \mathrm{~d}$ after unilateral dorsal rhizotomy $(100.0 \pm 5.2)$; lanes 4-6, on the contralateral side $5 \mathrm{~d}$ after dorsal rhizotomy $(72.4 \pm 3.6)$; lanes 7-9, DRG in normal, unoperated rats $(64.0 \pm 7.9)$. The mean value in lanes $1-3$ is higher than that in lanes $4-6(p<0.001)$, whereas the latter is not different from that in lanes $7-9(0.10$ $<p<0.20)$. $18 S$ ribosomal $R N A$ : lanes 1-3 (100.0 \pm 3.6$)$; lanes 4-6 (96.0 \pm $6.9)$; lanes $7-9(92.1 \pm 2.6)$. The internal control with $18 \mathrm{~S}$ ribosomal RNA shows no significant difference among any three lanes. the last day of chronic NGF application was found to contain $52 \pm 15 \mathrm{pg} / \mathrm{ml}(n=4)$ of NGF (about $2 \mathrm{pm})$. The level of NGF in the serum sampled from normal rats was below our detection limit $(15 \mathrm{pg} / \mathrm{ml})$.

Figure 5 compares the effects of two concentration levels of NGF applied to the cut left sciatic nerve for $12 \mathrm{~d}$ without dorsal rhizotomy. Compared with the application of a low concentration of NGF (Fig. $5 A ; 0.055 \mathrm{mg} / \mathrm{ml}$ ), the application of a 10 fold higher NGF (Fig. $5 B ; 0.55 \mathrm{mg} / \mathrm{ml}$ ) increased further the CGRP content in the DRG on the operated side (L, by about 3 -fold) as well as on the contralateral side ( $\mathrm{R}$, by about 1.4fold). To compare the effects of the same concentration of NGF on the CGRP content in DRG between the control and sciatic transected sides, a solution containing $0.55 \mathrm{mg} / \mathrm{ml}$ of NGF was infused subcutaneously for $12 \mathrm{~d}$ after section of the left sciatic nerve. Under this condition, the CGRP content in the DRG on the control side increased to the same level (Fig. $5 C, \mathrm{R}$ ) as that observed with NGF infusion to the left cut nerve (Fig. $5 B, \mathrm{R}$ ). This is consistent with the above suggestion that some NGF applied to the cut nerve leaks into blood circulation. However, CGRP levels in the DRG on the operated side showed no sign of increment in response to systemic NGF (Fig. $5 C$, L). Thus, CGRP levels in the DRG following peripheral axotomy could be increased by infusion of NGF into the cut nerve end, but this required higher concentrations of NGF than those sufficient for upregulation of CGRP levels in intact DRG.

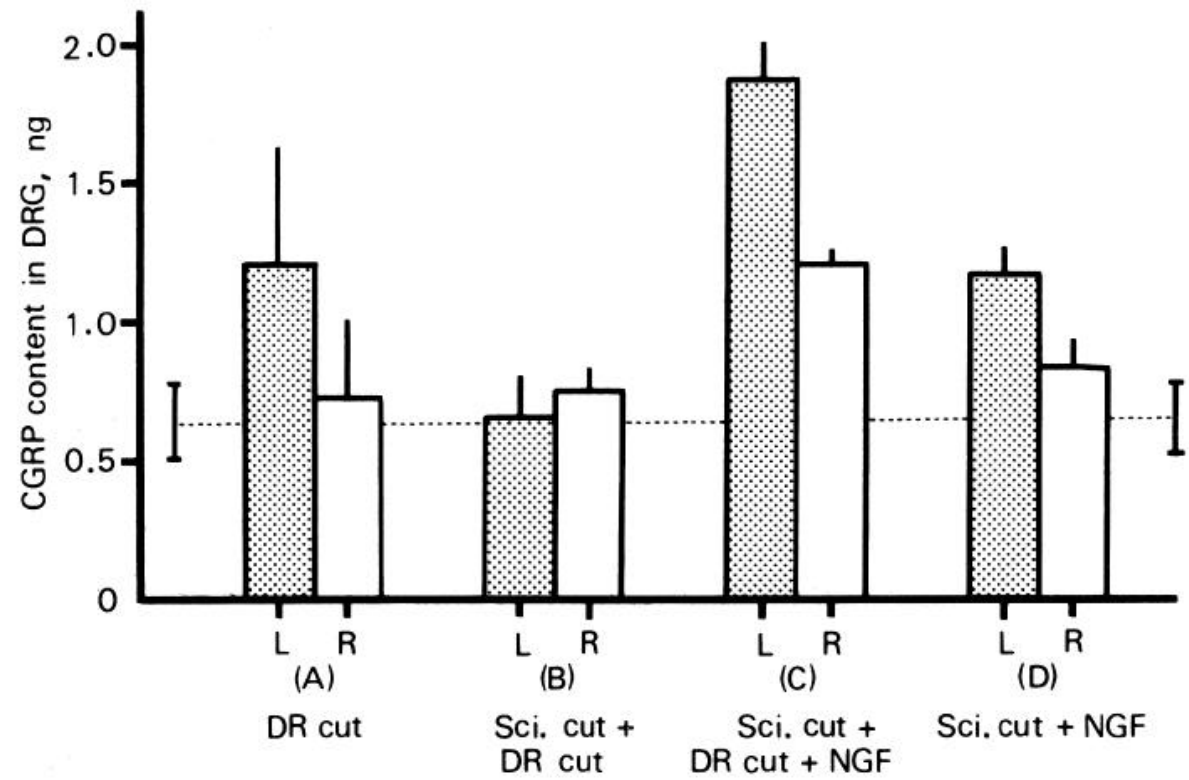

Figure 4. Dependence of increment of CGRP levels induced in DRG by dorsal rhizotomy upon the peripheral processes and NGF. Shaded columns, CGRP contents in the lumbar DRG on the operated side $(L)$. Open columns, CGRP contents in DRG on the contralateral side $(R)$. Each column represents the mean with SD (vertical bars) from three to five rats. Broken horizontal line, the mean CGRP content of DRG in normal rats with SD shown on both ends. $A$, Five days after dorsal rhizotomy on the left side. $B$, Same as in $A$, but the left sciatic nerve had been cut 1 week previously. $C$, Same as in $B$, but NGF $(0.055 \mathrm{mg} / \mathrm{ml})$ was infused into the cut left sciatic nerve for the $12 \mathrm{~d}$ period. $D, N G F$ was infused to the cut left sciatic nerve for $12 \mathrm{~d}$ without dorsal rhizotomy. 


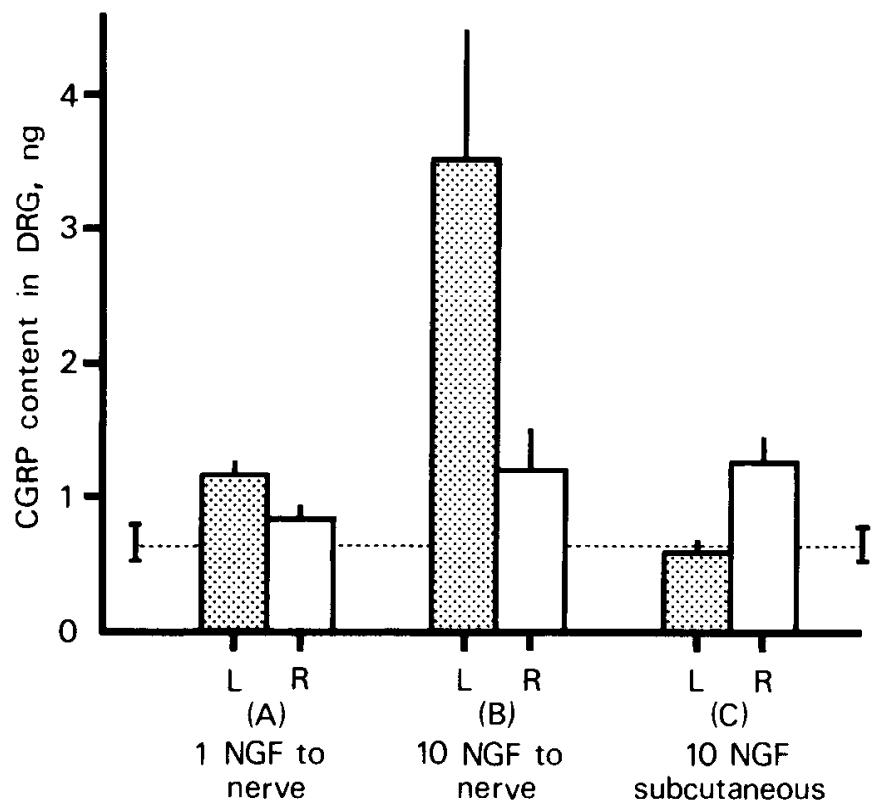

Figure 5. Effects of NGF on CGRP contents in axotomized and intact DRG. CGRP contents in DRG were measured on the operated side ( haded columns, $L$ ) and on the contralateral side (open columns, $R$ ) 12 $\mathrm{d}$ after section of the left sciatic nerve. Each column represents the mean with SD (vertical bars) from three or four rats. Broken horizontal line, the mean CGRP content of DRG in normal rats with SD shown on both ends. $A$, NGF $(0.055 \mathrm{mg} / \mathrm{ml})$ was infused to the cut left sciatic nerve for $12 \mathrm{~d}$. $B$, A 10 -fold higher concentration of NGF $(0.55 \mathrm{mg} /$ $\mathrm{ml}$ ) was infused in the cut left sciatic nerve for $12 \mathrm{~d}$. $C$, Same as in $B$, but NGF was applied subcutaneously.

\section{Discussion}

\section{Upregulation of CGRP expression in DRG by dorsal rhizotomy}

It is well known that DRG cells show chromatolysis after section of their peripheral axons but not following section of their central processes (Cragg, 1970; Lieberman, 1971). Similarly, changes of protein synthesis observed in DRG cells after peripheral axotomy are not detected following central axotomy (Hall, 1982; Perry et al., 1983). Moreover, sensory neurons reduce their conduction velocity following peripheral axotomy but not after central axotomy (Czeh et al., 1977). Therefore, interactions of sensory neurons with their targets appear to be different in nature between their central and peripheral processes. Recently, the cxpression of tubulin mRNA in DRG cclls has becn shown to be enhanced by peripheral axotomy, whereas central axotomy induces a prolonged reduction of its expression (Wong and $\mathrm{Ob}-$ linger, 1990). This reciprocal regulation of tubulin mRNA levels resembles differential regulation of the CGRP content in DRG cells via their central and peripheral processes.

How dorsal rhizotomy increases CGRP levels in the DRG is a matter of speculation at present. Two possibilities may be considered. First, a trophic factor acquired by sensory neurons via their central processes may be involved in downregulation of CGRP levels; interruption of the normal supply of this factor by central axotomy would then increase CGRP levels in the DRG. As exemplified by brain-derived neurotrophic factor (Davies et al., 1986; Hofer and Barde, 1988), the trophic factors for DRG cells derived from the central and peripheral processes may not be identical. Second, some molecules synthesized in
DRG cells and transported via their central processes or their degradation products may be transported retrogradely back to the DRG for stimulation of CGRP synthesis; central axotomy would increase the amount of such material transported back to the DRG, thereby increasing its CGRP content. Such material does not seem to be present in the peripheral processes of DRG. This implies that sensory neurons may be capable of transporting distinct materials selectively along their central and peripheral processes (Ochs et al., 1978).

It has been reported that dorsal rhizotomy does not affect the expression of substance P in the DRG (Jessell et al., 1979; Noguchi et al., 1989; Henken et al., 1990). Therefore, the levels of CGRP and substance $P$ in sensory neurons may employ different regulatory systems in vivo. However, Villar et al. (1991) have recently shown that the levels of substance $P$ and galanin in DRG are also increased slightly but significantly 2 weeks after section of the dorsal root.

\section{Interactions of centrally and peripherally derived regulatory effects}

When the sciatic nerve had been cut 1 week previously, dorsal rhizotomy failed to increase CGRP levels in the lumbar DRG. However, if NGF had been infused into the cut peripheral nerve, dorsal rhizotomy was again effective in increasing CGRP levels in the DRG. The simplest interpretation of these results would be that upregulation of CGRP levels in the DRG by dorsal rhizotomy depends upon the availability of NGF normally supplied from the periphery. However, CGRP levels in the DRG were little affected for $9 \mathrm{~d}$ by peripheral axotomy alone (Fig. $1 A$ ). Thus, upregulation of CGRP levels in the DRG by dorsal rhizotomy may be curtailed by a slight reduction of NGF derived from the periphery, which, by itself, is not sufficient to influence the CGRP content in the DRG. Then, NGF seems to act as a set point for the degree of upregulation of CGRP levels in the DRG induced by dorsal rhizotomy. This suggests that NGF may be a permissive factor, rather than an instructive factor, for regulation of CGRP levels in sensory neurons, as reported for the process of transmitter choice by sympathetic neurons (Patterson, 1978).

CGRP-immunoreactive cells constitute $40-50 \%$ of DRG neurons (Ju et al., 1987; Lindsay et al., 1989; McCarthy and Lawson, 1990). While CGRP-positive cells are mainly those sensory neurons with fibers of slow conduction velocities (C and $\mathrm{A} \delta$ ), 10$15 \%$ of CGRP-positive cells are identified as $\mathrm{A} \alpha / \beta$ neurons by their conduction velocities ( $>12 \mathrm{~m} / \mathrm{sec}$; McCarthy and Lawson, 1990). It is not certain whether NGF upregulates CGRP in both the small $(\mathrm{C}$ and $\mathrm{A} \delta)$ and large $(\mathrm{A} \alpha / \beta)$ sensory neurons. Treatment with NGF can prevent the cell death induced by axotomy in small sensory neurons but not in large A $\alpha$ sensory neurons (Miyata et al., 1986). Also, exposure to anti-NGF antibodies results in a preferential loss of small sensory neurons (Johnson et al., 1980). However, central synaptic function of the large $A \alpha$ sensory neurons once depressed following peripheral axotomy can be reversed by NGF (Miyata et al., 1986). Thus, the small sensory neurons may be more responsive to NGF, but the large sensory neurons are also functionally responsive to NGF. The expression of vasoactive intestinal polypeptide is known to be independent of NGF (Mulderry and Lindsay, 1990), yet this peptide coexists with CGRP in some of the small sensory neurons (Ju et al., 1987). Moreover, heart cell-conditioned media contain multiple factors, each of which regulates independently the synthesis of different neuropeptides in sympathetic neurons 
(Nawa and Patterson, 1990; Nawa and Sah, 1990). Taken together, regulation of the neuropeptide expression by trophic factors appears to be peptide specific rather than neuron specific. It is then likely that NGF upregulates CGRP in sensory neurons, regardless of the neuron size. However, this assumption remains to be evaluated.

\section{Effects of NGF applied to the cut nerve end}

When NGF was applied to the cut nerve end on one side, the CGRP content in the DRG on the contralateral side was also elevated, presumably by the leakage of the applied NGF into blood circulation. The serum level of NGF under this condition was about $2 \mathrm{pM}$. This is approximately 10 times lower than the $K_{d}$ for the high-affinity class of NGF receptors (Sutter et al., 1979). When a 10-fold higher concentration of NGF was systemically applied, the CGRP content in the DRG on the control side was further increased, whereas the CGRP content in the DRG whose peripheral processes had been cut did not show any increase. These results suggest two possibilities. First, the cut nerve end may have only low-affinity NGF receptors, so that CGRP levels in axotomized DRG cells increase only when high concentrations of NGF are applied directly to the cut nerve end. This possibility may conflict with the current view that biological effects of NGF are exerted by internalization of NGF as a result of binding to the high-affinity receptor (Bernd and Greene, 1984). In cultured Schwann cells, however, cellular responses to NGF can be induced apparently through the lowaffinity receptor (Seilheimer and Schachner, 1987). Second, the density of high-affinity NGF receptors in sensory neurons, including their peripheral processes, may be reduced markedly following peripheral axotomy (Verge et al., 1989). Thus, CGRP levels in axotomized DRG cells may remain unchanged when relatively low doses of NGF are applied systemically. Since NGF regulates the NGF receptor gene expression (Lindsay et al., 1990; Miller et al., 1991), a reduction in the density of NGF receptors induced by peripheral axotomy can be restored by NGF infused to the cut nerve end (Verge et al., 1989).

\section{A signal from Schwann cells around degenerating fibers}

There have been long-standing awkward observations that section of the peripheral nerve on one side induces a variety of changes in motor or sensory neurons on the contralateral side (Lieberman, 1971; Villar et al., 1989; Noguchi et al., 1990; Wong and Oblinger, 1990). We also observed that CGRP levels in DRG on the contralateral side increase $9 \mathrm{~d}$ after unilateral section of the sciatic nerve. However, this effect disappeared if the entire hindlimb below the site of nerve section had been removed (Fig. $1 B$ ). This suggests that the contralateral effect is induced by some humoral signal derived from the region peripheral to the site of nerve section. We hypothesize that this signal may be NGF synthesized in Schwann cells around degenerating nerve fibers (Heumann et al., 1987a,b), which may be released to blood circulation. The local production of NGF by Schwann cells may be beneficial for regenerating nerve fibers at the injury site (Heumann et al., 1987a,b; Johnson et al., 1988; Taniuchi et al., 1988). However, NGF synthesized by Schwann cells in response to nerve injury may act not only locally but also more generally in the blood-borne form.

\section{References}

Bernd P, Greene LA (1984) Association of ${ }^{125}$ I-nerve growth factor with $\mathrm{PC} 12$ pheochromocytoma cells. Evidence for internalization via high-affinity receptors only and for long-term regulation by nerve growth factor of high- and low-affinity receptors. J Biol Chem 259: $15509-15516$.

Bisby MA, Keen P (1986) Regencration of primary afferent neurons containing substance-P-like immunoactivity. Brain Res 365:85-95.

Cragg BG (1970) What is the signal for chromatolysis? Brain Res 23: $1-21$.

Czeh G, Kudo N, Kuno M (1977) Membrane properties and conduction velocity in sensory neurones following central or peripheral axotomy. J Physiol (Lond) 270:165-180.

Davies AM, Thoenen H, Barde YA (1986) Different factors from the central nervous system and periphery regulate the survival of sensory neurons. Nature 319:497-499.

Feinberg AP, Vogelstein B (1983) A technique for radio-labelling DNA restriction endonuclease fragments to high specific activity. Anal Biochem 132:6-13.

Fitzgerald M, Wall PD, Goedert M, Emson PC (1985) Nerve growth factor counteracts the neurophysiological and neurochemical cffects of chronic sciatic nerve section. Brain Res 332:131-141.

Furukawa S, Kamo I, Furukawa Y, Akazawa S, Satoyoshi E, Itoh K, Hayashi K (1983) A highly sensitive enzyme immunoassay for mouse nerve growth factor. J Neurochem 40:734-744.

Goedert M, Stockel K, Otten U (1981) Biological importance of the retrograde transport of nerve growth factor in sensory neurons. Proc Natl Acad Sci USA 78:5895-5898.

Hall ME (1982) Changes in synthesis of specific proteins in axotomized dorsal root ganglia. Exp Neurol 76:83-93.

Henken DB, Battisti WP, Chesselet MF, Murray M, Tessler A (1990) Expression of $\beta$-preprotachykinin mRNA and tachykinins in rat dorsal root ganglion cells following peripheral or central axotomy. Neuroscience 39:733-742.

Heumann R, Korsching S, Bandtlow C, Thoenen H (1987a) Changes of nerve growth factor synthesis in nonneuronal cells in response to sciatic nerve transection. J Cell Biol 104:1623-1631.

Heumann R, Lindholm D, Bandtlow C, Meyer M, Radeke MJ, Misko TP, Shooter E, Thoenen H (1987b) Differential regulation of mRNA encoding nerve growth factor and its receptor in rat sciatic nerve during development, degeneration, and regeneration: role of macrophages. Proc Natl Acad Sci USA 84:8735-8739.

Hofer MM, Barde YA (1988) Brain-derived neurotrophic factor prevents neuronal death in vivo. Nature 331:261-262.

Hökfelt T, Lundberg JM, Schultzberg M, Johansson O, Skirboll L, Anggard A, Fredholm B, Hamberger B, Pernow B, Rehfeld J, Goldstein M (1980) Cellular localization of peptides in neural structures. Proc R Soc Lond [Biol] 210:63-77.

Hökfelt T, Holets VR, Staines W, Meister B, Melander T, Schalling M, Schultzberg M, Freedman J, Bjorklund H, Olson L, Lindh B, Elfvin LG, Lundberg JM, Lindgren JA, Samuelsson B, Pernow B, Terenius L, Post C, Everitt B, Goldstein M (1986) Coexistence of neuronal messengers-an overview. Prog Brain Res 68:33-70.

Jessell T, Tsunoo A, Kanazawa I, Otsuka M (1979) Substance P in the dorsal horn of rat spinal cord after section of the peripheral processes of primary sensory neurons. Brain Res 168:247-259.

Johnson EM, Gorin PD, Brandeis LD, Pearson I (1980) Dorsal root ganglion neurons are destroyed by exposure in utero to maternal antibody to nerve growth factor. Science 210:916-918.

Johnson EM, Taniuchi M, DiStefano PS (1988) Expression and possible function of nerve growth factor receptors on Schwann cells. Trends Neurosci 11:299-304.

Ju G, Hökfelt T, Brodin E, Fahrenkrug J, Fischer JA, Frey P, Elde RP, Brown JC (1987) Primary sensory neurons of the rat showing calcitonin gene-related peptide immunoreactivity and their relation to substance P-, somatostatin-, galanin-, vasoactive intestinal polypeptide- and cholecystokinin-immunoreactive ganglion cells. Cell Tissue Res 247:417-431.

Kashihara Y, Sakaguchi M, Kuno M (1989) Axonal transport and distribution of endogenous calcitonin gene-related peptide in rat peripheral nerve. J Neurosci 9:3796-3802.

Korsching S, Thoenen H (1983) Nerve growth factor in sympathetic ganglia and corresponding target organs of the rats: correlation with density of sympathetic innervation. Proc Natl Acad Sci USA 80: 3513-3516.

Lieberman AR (1971) The axon reaction: a review of the principal features of perikaryal responses to axon injury. Int Rev Neurobiol $14: 49-124$. 
Lindsay RM, Harmar AJ (1989) Nerve growth factor regulates expression of neuropeptide genes in adult sensory neurons. Nature 337: 362-364.

Lindsay RM, Locket C, Sternberg J, Winter J (1989) Neuropeptide expression in cultures of adult sensory neurons: modulation of substance $\mathrm{P}$ and calcitonin gene-related peptide levels by nerve growth factor. Neuroscience 33:53-65.

Lindsay RM, Shooter EM, Radeke M, Misko TP, Dechant G, Thoenen H, Lindholm D (1990) Nerve growth factor regulates expression of the nerve growth factor receptor gene in adult sensory neurons. Eur J Neurosci 2:389-396.

McCarthy PW, Lawson SN (1990) Cell type and conduction velocity of rat primary sensory neurons with calcitonin gene-related peptidelike immunoreactivity. Neuroscience 34:623-632.

McMahon SB, Gibson S (1987) Peptide expression is altered when afferent nerves reinnervate inappropriate tissue. Neurosci Lett 73:915.

Miller FD, Mathew TC, Toma JG (1991) Regulation of nerve growth factor receptor gene expression by nerve growth factor in the developing peripheral nervous system. J Cell Biol 112:303-312.

Miyata Y, Kashihara Y, Homma S, Kuno M (1986) Effects of nerve growth factor on the survival and synaptic function of Ia sensory neurons axotomized in neonatal rats. J Neurosci 6:2012-2018.

Mulderry PK, Lindsay RM (1990) Rat dorsal root ganglion neurons in culture express vasoactive intestinal polypeptide (VIP) independently of nerve growth factor. Neurosci Lett 108:314-320.

Nawa H, Patterson PH (1990) Separation and partial characterization of neuropeptide-inducing factors in heart cell conditioned medium. Neuron 4:269-277.

Nawa H, Sah DWY (1990) Distinct factors in conditioned media control the expression of a variety of neuropeptides in cultured sympathetic neurons. Neuron 4:279-287.

Nielsch U, Keen P (1989) Reciprocal regulation of tachykinin- and vasoactive intestinal peptide-gene expression in rat sensory neurones following cut and crush injury. Brain Res 481:25-30.

Noguchi K, Senba E, Morita Y, Sato M, Tohyama M (1989) PreproVIP and preprotachykinin mRNAs in the rat dorsal root ganglion cells following peripheral axotomy. Mol Brain Res 6:327-330.

Noguchi K, Senba E, Morita Y, Sato M, Tohyama M (1990) $\alpha$-CGRP and $\beta$-CGRP mRNAs are differentially regulated in the rat spinal cord and dorsal root ganglion. Mol Brain Res 7:299-304.

O'Brien C, Woolf CJ, Fitzgerald M, Lindsay RM, Molander C (1989) Differences in the chemical expression of rat primary afferent neurons which innervate skin, muscle or joint. Neuroscience 32:493-502.

Ochs S, Erdman J, Jersild RA, McAdoo V (1978) Routing of transported materials in the dorsal root and nerve fiber branches of the dorsal root ganglion. J Neurobiol 9:465-481.
Patterson PH (1978) Environmental determination of autonomic ncurotransmitter functions. Annu Rev Neurosci 1:1-17.

Perry GW, Krayanek SR, Wilson DL (1983) Protein synthesis and rapid axonal transport during regrowth of dorsal root axons. J Neurochem 40:1590-1598.

Price J (1985) An immunohistochemical and quantitative examination of dorsal root ganglion neuronal subpopulations. J Neurosci 5: 2051-2059.

Seilheimer B, Schachner M (1987) Regulation of neural cell adhesion molecule expression on cultured mouse Schwann cells by nerve growth factor. EMBO J 6:1611-1616.

Sutter A, Riopelle RJ, Harris-Warrick RM, Shooter EM (1979) Nerve growth factor receptors. Characterization of two distinct classes of binding sites on chick embryo sensory ganglia cells. J Biol Chem 254: 5972-5982.

Taniuchi M, Clark HB, Johnson EM (1986) Induction of nerve growth factor receptor in Schwann cells after axotomy. Proc Natl Acad Sci USA 83:4094-4098.

Taniuchi M, Clark HB, Schweitzer JB, Johnson EM (1988) Expression of nerve growth factor receptors by Schwann cells of axotomized peripheral nerves: ultrastructural location, suppression by axonal contact and binding properties. J Neurosci 8:664-681.

Varon S, Nomura J, Perez-Polo JR, Shooter EM, Kennedy JP (1972) The isolation and assay of the nerve growth factor proteins. In: Methods of neurochemistry, Vol 3 (Fried M, ed), pp 203-229. New York: Dekker.

Verge VMK, Riopelle RJ, Richardson PM (1989) Nerve growth factor receptors on normal and injured sensory neurons. J Neurosci 9:914922.

Villar MJ, Cortes R, Theodorsson E, Wiesenfeld-Hallin Z, Schalling M, Fahrenkrug J, Emson PC, Hökfelt T (1989) Neuropeptide expression in rat dorsal root ganglion cells and spinal cord after peripheral nerve injury with special reference to galanin. Neuroscience 33:587604.

Villar MJ, Wiesenfeld-Hallin Z, Xu XJ, Theodorsson E, Emson PC, Hökfelt $T$ (1991) Further studies on galanin-, substance $P$-, and CGRP-like immunoreactivities in primary sensory neurons and spinal cord: effects of dorsal rhizotomy and sciatic nerve lesions. Exp Neurol 112:29-39.

Wong J, Oblinger MM (1990) A comparison of peripheral and central axotomy effects on neurofilament and tubulin gene expression in rat dorsal root ganglion neurons. J Neurosci 10:2215-2222.

Wong J, Oblinger MM (1991) NGF rescues substance P expression but not neurofilament or tubulin gene expression in axotomized sensory neurons. J Neurosci 11:543-552. 